\title{
Article \\ A Molecule of the Viridomycin Family Originating from a Streptomyces griseus-Related Strain Has the Ability to Solubilize Rock Phosphate and to Inhibit Microbial Growth
}

\author{
Hanane Hamdali ${ }^{1}$, Ahmed Lebrihi ${ }^{2}$, Marie Carmen Monje ${ }^{2}$, Ahmed Benharref ${ }^{3}$, Mohamed Hafidi ${ }^{3,4}$, \\ Yedir Ouhdouch ${ }^{3,4}$ (D) and Marie Joëlle Virolle ${ }^{5, *}$
}

1 Laboratory of Biotechnology and Valorization of Plant Genetic Resources, Faculty of Sciences and Techniques, University of Sultan Moulay Slimane, P.O. Box 523, Beni-Mellal 23000, Morocco; hamdali_hanane@yahoo.fr

2 INPT, Laboratoire de Génie Chimique, UMR 5503 (CNRS/INPT/UPS), École Nationale Supérieure d'Agronomie de Toulouse, 1, Avenue de l'Agrobiopôle, B.P. 107, F-31 326 Castanet-Tolosan CEDEX, France; ahmed.lebrihi@ensat.fr (A.L.); monje@pop.ensat.fr (M.C.M.)

3 Laboratoire of Microbial Biotechnologies, Agrosciences and Environment, Université Cadi Ayyad (UCA), Boulevard Prince My Abdellah B.P. 2390, Marrakech 40000, Morocco; benharref@uca.ac.ma (A.B.); hafidi.ucam@gmail.com (M.H.); youhdouch@gmail.com (Y.O.)

4 AgroBioSciences Program, Mohammed VI Polytechnic University (UM6P), Benguerir 43150, Morocco

5 CEA, CNRS, Institute for Integrative Biology of the Cell (I2BC), Université Paris-Saclay, 91198 Gif-sur-Yvette, France

* Correspondence: marie-joelle.virolle@i2bc.paris-saclay.fr; Tel.: +33-169156197

\section{check for}

updates

Citation: Hamdali, H.; Lebrihi, A.; Monje, M.C.; Benharref, A.; Hafidi, M.; Ouhdouch, Y.; Virolle, M.J. A

Molecule of the Viridomycin Family Originating from a Streptomyces griseus-Related Strain Has the Ability to Solubilize Rock Phosphate and to Inhibit Microbial Growth. Antibiotics 2021, 10, 72. https://doi.org/ $10.3390 /$ antibiotics 10010072

Received: 29 December 2020 Accepted: 12 January 2021 Published: 14 January 2021

Publisher's Note: MDPI stays neutral with regard to jurisdictional clai$\mathrm{ms}$ in published maps and institutional affiliations.

Copyright: (C) 2021 by the authors. Licensee MDPI, Basel, Switzerland. This article is an open access article distributed under the terms and conditions of the Creative Commons Attribution (CC BY) license (https:// creativecommons.org/licenses/by/ $4.0 /)$.

\begin{abstract}
Some soil-borne microorganisms are known to have the ability to solubilize insoluble rock phosphate and this process often involves the excretion of organic acids. In this issue, we describe the characterization of a novel solubilizing mechanism used by a Streptomyces strain related to Streptomyces griseus isolated from Moroccan phosphate mines. This process involves the excretion of a compound belonging to the viridomycin family that was shown to play a major role in the rock phosphate bio weathering process. We propose that the chelation of the positively charged counter ions of phosphate constitutive of rock phosphate by this molecule leads to the destabilization of the structure of rock phosphate. This would result in the solubilization of the negatively charged phosphates, making them available for plant nutrition. Furthermore, this compound was shown to inhibit growth of fungi and Gram positive bacteria, and this antibiotic activity might be due to its strong ability to chelate iron, a metallic ion indispensable for microbial growth. Considering its interesting properties, this metabolite or strains producing it could contribute to the development of sustainable agriculture acting as a novel type of slow release bio-phosphate fertilizer that has also the interesting ability to limit the growth of some common plant pathogens.
\end{abstract}

Keywords: Streptomyces griseus; viridomycin; antimicrobial activity; rock phosphate solubilization

\section{Introduction}

Phosphorus $(\mathrm{P})$ is often scarce in natural soils and its low availability limits plant growth and thus agricultural yields [1,2]. To solve this problem, agricultural soils are amended with soluble phosphate. However, the generation of soluble phosphate from natural rock phosphate (RP) is expensive and highly polluting and alternatives should be found. Natural ground RP was used in traditional agriculture with limited success because of its poor solubility. Interestingly several reports in the literature mentioned that some soil-borne microorganisms are able to solubilize mineral phosphates and are thus of great interest to enhance $\mathrm{P}$ availability for plant nutrition $[2,3]$. The introduction of such microorganisms in fields might constitute a way to reduce soluble phosphate fertilizer input $[1,2,4]$. The commercially available poorly soluble RP is mainly a calcium hydroxyapatite $\left[\mathrm{Ca}_{10}\left(\mathrm{PO}_{4}\right)_{6} \mathrm{OH}\right]$ but calcium could be substituted by other cations such 
as $\mathrm{Fe}^{3+}, \mathrm{Al}^{3+}, \mathrm{Na}^{+}$, and $\mathrm{Mg}^{2+}$ ions [5]. Numerous reports in the literature mention that most Phosphate Solubilizing Microorganisms (PSM) dissolve insoluble mineral phosphates via secretion of organic acids [6]. In addition, some PSM can contribute to plant health via the production of bioactive substances, limiting the growth of some specific plants pathogens $[7,8]$. Their use could thus reduce the excessive input of chemical pesticides that are known to be toxic to human health [9]. Among these PSM, Actinobacteria [10-14] are of special interest. These filamentous and spore-forming bacteria contribute to soil fertility through their valuable ability to decompose soil organic matter. They also contribute to plant health and fitness thanks to their ability to produce molecules able to limit the growth of devastating bacterial or fungal phytopathogenic agents $[15,16]$. We previously isolated from Moroccan phosphate mine and characterized a Streptomyces griseus-related strain able to efficiently solubilize RP [10] as well as to produce antifungal and anti-bacterial metabolites [11,12]. In this issue we demonstrated that the RP solubilization ability of this strain was due to excretion of a molecule of the viridomycin family. This molecule can allow the slow release of the phosphate of RP via its ability to chelate the positively charged counter ions of the phosphate constitutive of RP.

\section{Results}

\subsection{Detection and Purification of Bio-Active Fractions}

The cell-free supernatant of $3 \mathrm{~L}$ cultures of the Streptomyces griseus-related strain grown as described in Materials and Methods was extracted with isoamyl alcohol. The resulting greenish organic phase was concentrated to dryness $(1.65 \mathrm{~g})$, dissolved in $2 \mathrm{~mL}$ of methanol as a crude extract, and analyzed by Thin Layer Chromatography (TLC). After migration and revelation, four active spots were detected by bio autography on the TLC plates. The four fractions designated as A, B, C, and D showed Rf values of $0.9,0.45,0.37$, and 0.3, respectively. A and D spots showed both antibacterial and antifungal activities against the tested micro-organisms, while $B$ and $C$ showed only antibacterial activity (see material and methods; (Figure 1). Subsequently, the crude extract $(275 \mathrm{mg} / \mathrm{mL})$ was deposited on preparative silica gel plates in order to collect the $\mathrm{A}$ and $\mathrm{D}$ fractions in sufficient quantity. We obtained $115 \mathrm{mg} / \mathrm{mL}$ of fraction A ( $41.8 \%$ of crude extract) and $98.5 \mathrm{mg} / \mathrm{mL}$ of fraction D (35.8\% of crude extract) (Figure 1$)$.

\subsection{Determination of the Mineral Phosphate-Solubilizing Abilities of the Bio-Active Fractions}

In order to determine the mineral phosphate-solubilizing abilities of the bio-active fractions, $500 \mu \mathrm{L}$ of active fractions A and D at a final concentration $98.5 \mathrm{mg} / \mathrm{mL}$ were checked for their ability to solubilize RP and TCP (Tri-calcium phosphate, $\left.\mathrm{Ca}_{3}\left(\mathrm{PO}_{4}\right)_{2}\right)$ as described in material and methods (Figure 1). The results demonstrated that only fraction $\mathrm{D}$ (greenish color) showed an ability to solubilize RP as well as TCP. The concentrations of solubilized phosphate from RP and TCP were $63.7 \mu \mathrm{g} / \mathrm{mL}$ and $135.2 \mu \mathrm{g} / \mathrm{mL}$, respectively.

\subsection{HPLC Analysis of the Bio-Active Fraction D that Also Bears Mineral Phosphate-Solubilizing Ability}

The HPLC chromatogram of the active greenish fraction (D) revealed several peaks. The retention time of the main peaks $\mathrm{D}_{1}$ and $\mathrm{D}_{2}$ was 15.62 and $17.99 \mathrm{~min}$, respectively (Figure 2).

These sub-fractions were checked again for their ability to solubilize mineral phosphate and for their antibiotic activity against Micrococcus luteus ATCC 381 (ML), Bacillus subtilis ATCC 9524 (BS), Pythium ultimum BCCM 16,164 (PU), and Mucor ramannianus NRRL 1829 (MR) using the paper filter disk technique.

The purified $\mathrm{D}_{1}$ compound showed only antibacterial activity whereas the purified $\mathrm{D}_{2}$ compound showed both the ability to solubilize mineral phosphate of TCP and RP (Figure 2) as well as to inhibit the growth of all tested bacterial and fungal strains (Table 1). 


\section{$\downarrow$ Crude extract}

Organic phase

Preparative Thin Layer chromatography

$\downarrow$ (methanol/gradient 0 to $100 \%$ )

8 fractions

Bioautography, Silica gel column, ethyl acetate/methanol $(100: 15, v / v)$

4 active fractions $(\mathrm{A}, \mathrm{B}, \mathrm{C}, \mathrm{D})$

$B$ and $C$ showed only anti-bacterial activities $A$ and $D$ showed anti-bacterial and anti-fungi activities

Test for RP/TCP solubilizing activity

Only fraction D had RP/TCP solubilization ability HPLC purification

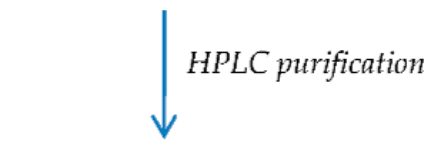

Fractions D1 and D2 $\frac{\text { Test for RP/TCP solubilizing activity }}{\text { Test for antimicrobial activities }}$
Compound of fraction D2 is a molecule of the Viridomvcin famillv.

Structure elucidation
Only fraction D2 had anti-bacterial and anti-fungal activity as well as phosphate solubilizing activity

Figure 1. Schematic representation of the workflow used to purify the molecule of the viridomycin family possessing both phosphate-solubilizing and antimicrobial activity. RP and TCP stand for Rock Phosphate and Tri Calcium Phosphate, respectively. HPLC stands for High Performance Liquid Chromatography.

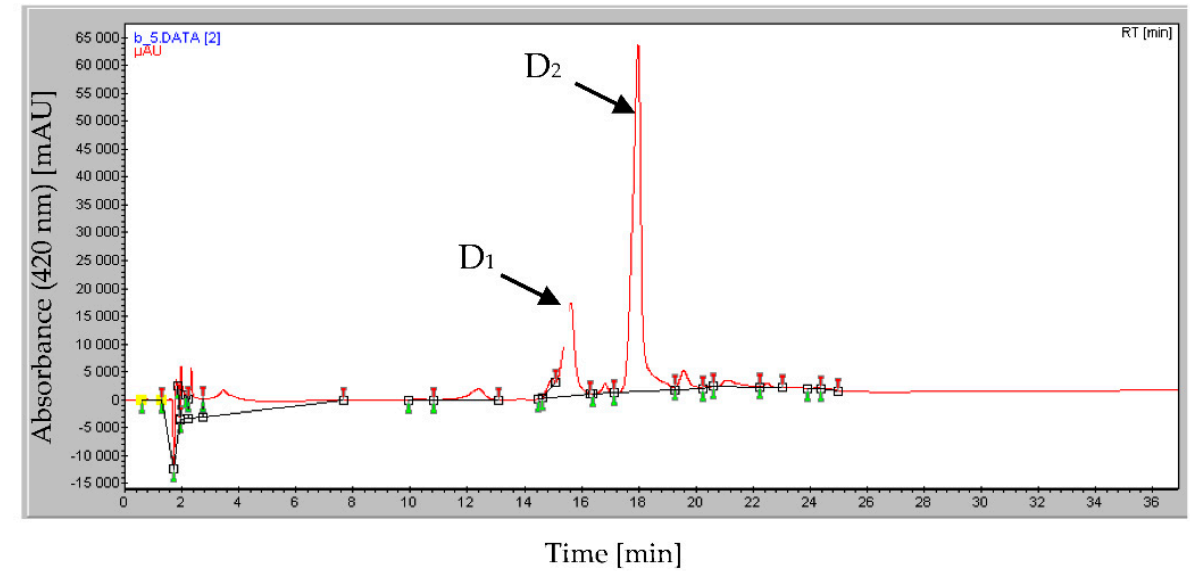

Figure 2. HPLC analysis of the fraction D bearing both antibiotic and rock phosphate-solubilizing activity. This fraction contains two main peaks, $D_{1}(R f=15.62)$ and $D_{2}(R f=17.99 \mathrm{~min})$. 
Table 1. Antimicrobial activity of the $\mathrm{D}_{2}$ compound.

\begin{tabular}{ccccc}
\hline & \multicolumn{4}{c}{ Antimicrobial Activity ${ }^{\text {a }}$ against } \\
\cline { 2 - 5 } & \multicolumn{2}{c}{ Gram Positive Bacteria } & Fungi \\
\cline { 2 - 5 } & $\begin{array}{c}\text { Bacillus subtilis } \\
\text { ATCC 9524 }\end{array}$ & $\begin{array}{c}\text { Micrococcus luteus } \\
\text { ATCC 381 }\end{array}$ & $\begin{array}{c}\text { Pythium ultimum } \\
\text { BCCM 16164 }\end{array}$ & $\begin{array}{c}\text { Mucor ramannianus } \\
\text { NRRL 1829 }\end{array}$ \\
\hline $\begin{array}{c}\text { Diameter of the } \\
\text { inhibition zone }(\mathrm{mm})\end{array}$ & $29 \pm 1.2$ & $45 \pm 1.4$ & $27 \pm 1.1$ & $38 \pm 1.0$ \\
\hline
\end{tabular}

a: Activity assessed by the agar diffusion method (filter disc i.d. $6 \mathrm{~mm}, \mathrm{c}=20 \mu \mathrm{g} / \mathrm{mL}, 20 \mu \mathrm{L} /$ disc).

Larger volumes of the pure active $\mathrm{D}_{2}$ fraction led to a higher release of solubilized phosphate from TCP and RP. For instance, $100 \mu \mathrm{L}$ and $500 \mu \mathrm{L}$ of the $\mathrm{D}_{2}$ fraction resulted in concentrations of solubilized phosphate of $28.6 \mu \mathrm{g} / \mathrm{mL}$ and $45.2 \mu \mathrm{g} / \mathrm{mL}$ from RP and $78.6 \mu \mathrm{g} / \mathrm{mL}$ and $110.7 \mu \mathrm{g} / \mathrm{mL}$ from TCP, respectively (Figure 3).

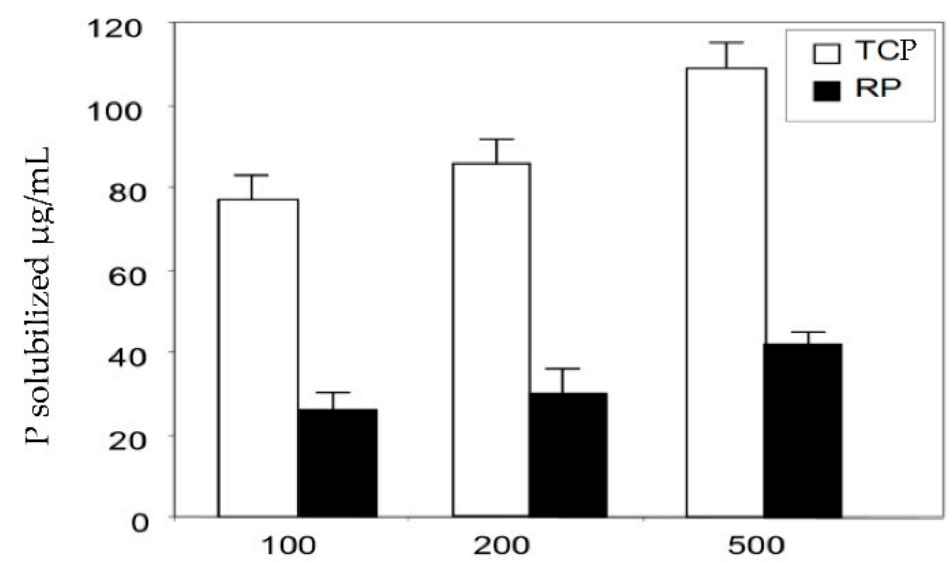

$\mathrm{D}_{2}$ compound $(\mu \mathrm{L})$

Figure 3. Phosphate released from TCP $(4 \mathrm{mg} / \mathrm{mL}$, white histograms) and RP $(1 \mathrm{mg} / \mathrm{mL}$, black histograms) incubated for five days at $30^{\circ} \mathrm{C}$ on a rotary shaker $(180 \mathrm{rpm})$ in the presence of 100,200 , and $500 \mu \mathrm{L}$ of purified compound $\mathrm{D}_{2}$ or an equivalent volume of sterile bi-distilled water (negative control). The amount of soluble phosphate released from RP and TCP of the negative control was subtracted from that present in the assays containing the purified compound $\mathrm{D}_{2}$. The final values are arithmetic means of three independent assays and error bars represent standard deviations of the mean values of the triplicates.

\subsection{Structural Determination of the Bio-Active Compound of Fraction $D_{2}$}

After purification, the structure of the active $\mathrm{D}_{2}$ compound $(30 \mathrm{mg})$ was elucidated by different spectroscopic methods. The HR-ESIMS and ${ }^{13} \mathrm{C}$ NMR spectra revealed that the molecular formula of the $\mathrm{D}_{2}$ compound was $\mathrm{C}_{21} \mathrm{H}_{12} \mathrm{O}_{9} \mathrm{~N}_{3} \mathrm{Fe}$. The ESIMS spectrum obtained in the full-can mass range $(\mathrm{m} / \mathrm{z}) \mathrm{100}-2000$ and in the negative mode showed two main peaks at $m / z 506(\mathrm{Calcd}, 506.1875)$ and at $m / z 1035$, corresponding to $(\mathrm{M}-\mathrm{H})^{-}$and $(2 \mathrm{M}+\mathrm{Na}-2 \mathrm{H})^{-}$, respectively. Table 2 summarizes the assignments of protons and carbons of the NMR spectrum of the $\mathrm{D}_{2}$ compound.

Analysis of ${ }^{13} \mathrm{C}$ NMR spectra and ${ }^{1} \mathrm{H}$ NMR spectra revealed the presence of a ketone group and an aldehyde group and three 'potential' aromatic protons on the same moiety. According to its atomic composition, to the NMR data, and to the green color of its chromophore moiety, we identified this compound as a 3-imino -4-oxo- cyclohexa-1,5diene-carbaldehydo residue. This compound is likely to constitute a monomer of the $\mathrm{D}_{2}$ compound (Figure 4a). 
Table 2. NMR Spectroscopic Data (500 MHz, $\mathrm{CD}_{3} \mathrm{CN}$ ) of the $\mathrm{D}_{2}$ Compound.

\begin{tabular}{cccc}
\hline Position & $\delta_{\mathbf{C}}$, Type & $\delta_{\mathbf{H}}(\mathbf{J}$ in Hz) & HMBC $^{\mathbf{a}}$ \\
\hline 1 & 182.0 & & \\
2 & 159.3 & & Observed \\
3 & 115.7 & $7.56 \mathrm{~s}$ & Observed \\
4 & 123.9 & & Observed \\
5 & 134.5 & $7.96 \mathrm{~d}(9)$ & \\
6 & 122.5 & $7.16 \mathrm{~d}(9)$ & Observed \\
7 & 190.5 & $9.78 \mathrm{~s}$ & \\
\hline
\end{tabular}

Coupling constants in Hertz are given in parentheses. ${ }^{a}$ : $\mathrm{HMBC}=$ heteronuclear multiple bond correlation.
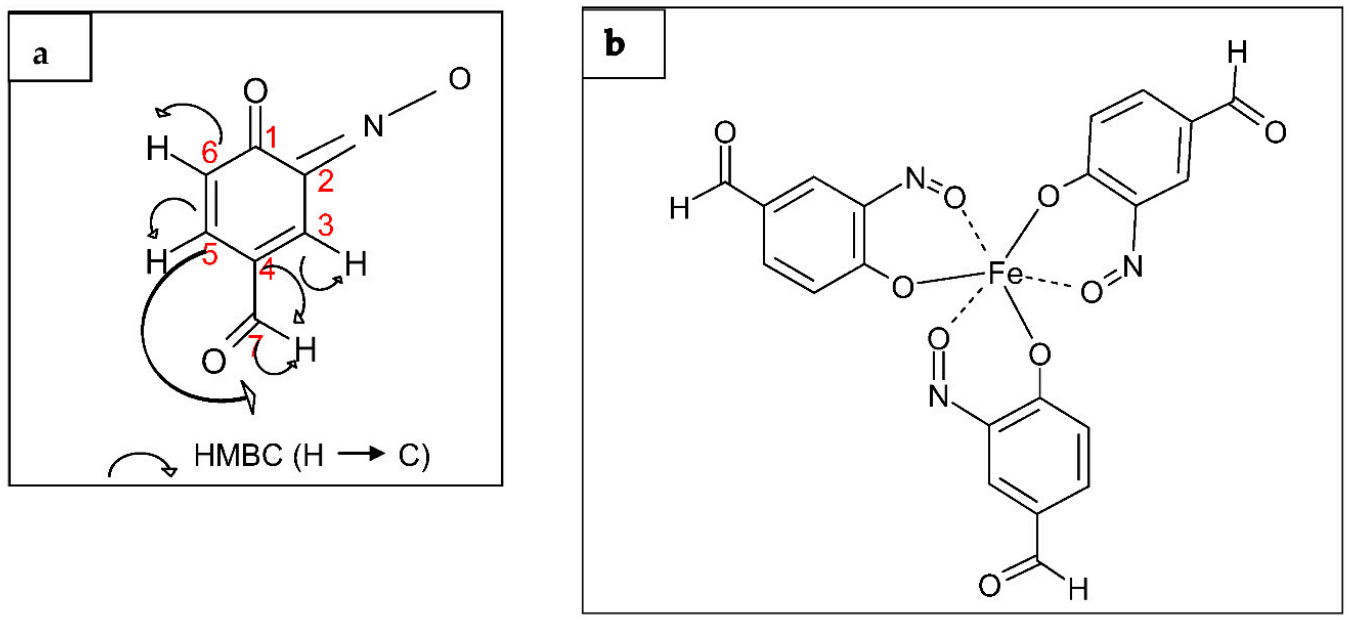

Figure 4. Structure and proposed mode of action of the viridomycin-like $\mathrm{D}_{2}$ compound (a) Monomer of the viridomycin-like $\mathrm{D}_{2}$ compound and HMBC correlation. (b) Proposed mode of action of the compound as an iron chelator.

The $\delta$ values and coupling patterns of four protons on the cyclohexane ring of the chromophore (Table 2) and the long-range couplings between the aldehyde proton and the ring carbons indicated that an aldehyde group was present at C-7 of the monomer (Figure 4a). The monomer should also have a ketone group at $\mathrm{C}-1$ and an oxim group $(-\mathrm{C}=\mathrm{N}-\mathrm{O})$ at $\mathrm{C}-2$ to be consistent with the molecular formula of $\mathrm{D}_{2}$ (Figure $4 \mathrm{a}$ ).

The result obtained with mass spectrometry and various NMR measurements (COSY, HSQC, HMBC, NOESY, DOSY) revealed that the structure of the $\mathrm{D}_{2}$ compound was identified as Tris (3-imino -4- oxo- cyclohexa-1,5-diene-carbaldehydo) iron (III) as shown in Figure $4 \mathrm{~b}$. This compound belongs to the viridomycin family and is similar to viridomycins A, E, and $\mathrm{F}$.

The greenish color of this compound suggested that it may contain iron. The presence of iron in this viridomycin-like molecule was thus tested and confirmed by the atomic absorption spectrophotometer method. The iron concentration was $0.26 \mathrm{mg}$ of Fe $e^{3+} / \mathrm{mg}$ of purified viridomycin, corresponding to approximately 2 moles of iron per mole of viridomycin.

\section{Discussion}

In this issue we demonstrated that a Streptomyces griseus-related strain that possesses multiple plant growth-promoting activities [10-12] produces a molecule of the viridomycin family [17] able to solubilize RP [11,13]. This family of molecules produced by some Actinobacteria was discovered in 1964 under the form of greenish pigments [18] constituted by a mixture of several molecules showing subtle structural differences and thus named viridomycins (A, B, C, D, E, and F) [19-21]. These molecules showed weak antibiotic activity that might be due to their ability to chelate iron, a metallic ion indispensable for microbial growth. Their production was shown to be triggered under the condition 
of phosphate limitation [18-21] but not under the condition of iron limitation [22]. This suggested that the first function of these molecules was to scavenge phosphate under the condition of phosphate limitation. However, our report is the first one to clearly demonstrate the ability of a molecule belonging to the viridomycin family to solubilize insoluble mineral phosphates. The capture by molecules of the viridomycin family of the positively charged counter ions of the P component of RP and TCP (including calcium, iron, etc ... ), is thought to destabilize the structure of RP or TCP, allowing the liberation and solubilization of the negatively charged phosphates.

Some other microorganisms, besides Actinobacteria [23-25], including Aspergillus niger [26], Enterobacter sp., Erwinia sp. [27], and Penicillium rugulosum [28] were also reported to solubilize insoluble RP by excretion of chelating substances able to form stable complexes with phosphorus counter-ions such as $\mathrm{Al}, \mathrm{Fe}$, and $\mathrm{Ca}$. These results were further supported by Narsian and Patel [29], who tested the effects of known chelators including EDTA, DTPA, NTA, aluminon, and oxine on RP solubilization. However the structure of these natural chelating molecules has never been characterized [30,31]. Furthermore, these metal chelating molecules/siderophores may act as antibiotics since they chelate metals, such as iron, that are indispensable for microbial growth [32,33].

We previously demonstrated that the introduction in greenhouse soil of the Streptomyces griseus-like strain producing metabolites of the viridomycin family had a positive effect on plant growth and fitness and was able to limit the detrimental effects of phytopathogen fungi $[12,13]$. Considering its interesting properties, the spreading of this strain or of strains with similar interesting properties in greenhouse and/or open air agricultural soils could contribute to the development of more sustainable agriculture since the molecules produced by these bacteria are indeed able to limit the growth of various plant pathogens as well as to make available for plant nutrition the phosphate present in poorly soluble ground rock phosphate used as a cheap amendment in traditional agriculture.

\section{Materials and Methods}

\subsection{Strain and Culture Conditions}

Spores of the Streptomyces griseus-related strain isolated from a Moroccan phosphate mine [10-13] were obtained from cultures grown on solid synthetic minimal medium [10] and stored in $20 \%$ sterile glycerol at $-20{ }^{\circ} \mathrm{C}$. These spores were used to inoculate (at $10^{6}$ spores $/ \mathrm{mL}$ ) a $3 \mathrm{~L}$ culture in a liquid synthetic minimal medium (glucose $1 \%, \mathrm{NaNO}_{3}$ $0.2 \%, \mathrm{MgSO}_{4} \cdot 7 \mathrm{H}_{2} \mathrm{O} 0.05 \%, \mathrm{KCl} 0.05 \%$, FeSO $4 \cdot 7 \mathrm{H}_{2} \mathrm{O} 0.001 \%$, pH 7.2) supplemented with $0.1 \%$ of washed RP as a sole phosphate source. Cultures were grown for five days at $28^{\circ} \mathrm{C}$ under constant agitation on a rotary shaker at $180 \mathrm{rpm}$. The rock phosphate used in this study is a calcium hydroxyapatite originating from the Khouribga phosphate mine (Morocco) constituted by O, 56.53\%; Ca, 16.35\%; P, 9.37\%; F, 2.42\%; Al, 2.03\%; Mg, 1.94\%; $\mathrm{Na}, 1.81 \% ; \mathrm{S}, 0.77 \% ; \mathrm{Fe}, 0.60 \%$, and $\mathrm{Sn}, 0.12 \%$ [10].

\subsection{Production and Extraction of Active Compounds}

The culture mentioned above was centrifuged at $10,000 \times \mathrm{g}$ for $10 \mathrm{~min}$. The collected supernatant was filtered through a $0.45 \mu \mathrm{m}$-pore-size filter (Supor-450; Pall Corporation, Port Washington, NY, USA) to remove cell debris. The filtrate was extracted with isoamyl alcohol (3-methyl butan-1-ol, Sigma, St. Quentin Fallavier Cedex, France), 100: $25(v / v)$ acidified to $\mathrm{pH} 2$ with $\mathrm{HCl} 6 \mathrm{~N}$. The greenish organic phase was collected and concentrated to dryness (1.65 g) under vacuum on a Rotavapor (Laborata 4000 , Heidolph) at $40{ }^{\circ} \mathrm{C}$ and then dissolved in $2 \mathrm{~mL}$ of $\mathrm{MeOH}$ to obtain the crude extract called $\mathrm{E}(275 \mathrm{mg} / \mathrm{mL})$.

\subsection{Detection and Purification of Active Fractions with Antimicrobial Activities}

In order to assess the presence of different bio-active metabolites in the crude extract by bio autography [34], volumes of $40 \mu \mathrm{L}$ and $60 \mu \mathrm{L}$ of the extract were spotted onto $20 \times 20$-cm silica gel plates (Merck Art. 5735, Kiessel gel 60F254) in order to assess its inhibitory activity against the Gram positive bacterium Bacillus subtilis ATCC 9524 and the 
fungus Pythium ultimum BCCM 16164, respectively. The TLC plates were developed using a mixture of ethyl acetate-methanol, 100: $15(v / v)$ and were air-dried overnight at $37^{\circ} \mathrm{C}$ to remove the solvents. After migration, the separated compounds were visualized at $254 \mathrm{~nm}$ under UV light (absorbance) and at $365 \mathrm{~nm}$ (fluorescence). The TLC plates were then placed in a plastic bioassay dish $\left(23 \times 23 \times 2.2 \mathrm{~cm}^{3}\right.$, Fisher Scientific Labosi) and overlaid with $150 \mathrm{~mL}$ of nutrient agar or PDA media (containing $7 \mathrm{~g} / \mathrm{L}$ of agar), inoculated with $B$. subtilis $\left(10^{6} \mathrm{cfu} / \mathrm{mL}\right)$ or P. ultimum $(100 \mathrm{cfu} / \mathrm{mL})$, respectively. Once the agar solidified, the plate was incubated at $30^{\circ} \mathrm{C}$. Four spots with bio-activity were detected by bio autography on the TLC plates. The four fractions designated as A, B, C, and D showed Rf values of $0.9,0.45,0.37$, and 0.3 , respectively. After $24 \mathrm{~h}$ of incubation for P. ultimum and $48 \mathrm{~h}$ for $B$. subtilis, clear areas corresponding to zones of growth inhibition of the microorganisms were detected, indicating the location of antibiotic compounds on the TLC plates. A and D spots showed both antibacterial and antifungal activities against the tested micro-organisms, while $B$ and $C$ showed only antibacterial activity.

Subsequently, the crude extract $(\mathrm{E}, 275 \mathrm{mg} / \mathrm{mL}$ ) was deposited on preparative silica gel plates in order to collect the $\mathrm{A}$ and $\mathrm{D}$ fractions in sufficient quantity. We obtained $115 \mathrm{mg} / \mathrm{mL}$ of fraction A ( $41.8 \%$ of total E) and $98.5 \mathrm{mg} / \mathrm{mL}$ of fraction $\mathrm{D}$ (35.8\% of total E).

\subsubsection{Antimicrobial Bioassay against Bacteria and Fungi}

The active fractions were collected and their antimicrobial activities were tested against two bacterial (Bacillus subtilis ATCC 9524 and Micrococcus luteus ATCC 381) and fungal (Pythium ultimum BCCM 16,164 and Mucor ramannianus NRRL 1829) species using the paper filter disk technique: To do so, $20 \mu \mathrm{L}$ of the active purified fractions were deposited on sterile cellulose disks ( $5 \mathrm{~mm}$ diameter, Pasteur Institute) and allowed to dry overnight at $37^{\circ} \mathrm{C}$ to evaporate the methanol solvent. Subsequently they were placed aseptically on the surface of plates of nutrient agar (Difco Maryland, USA) or of Sabouraud agar medium (Biorad, Schiltigheim, France) inoculated with bacteria at $10^{6} \mathrm{cfu} / \mathrm{mL}$ and fungi at $100 \mathrm{cfu} / \mathrm{mL}$, respectively. Sizes of the inhibition zones were determined after $24 \mathrm{~h}$ of incubation for Bacillus subtilis ATCC 9524 and Micrococcus luteus ATCC 381 and $48 \mathrm{~h}$ for Pythium ultimum BCCM 16,164 and Mucor ramannianus NRRL 1829. Controls consisted of sterile cellulose discs. Three replicates were performed for each fraction for each microorganism.

\subsubsection{Determination of Phosphate-Solubilizing Abilities}

In order to check the phosphate-solubilizing abilities of the active antimicrobial fractions, various volumes of the selected fractions or of sterile distilled water (negative control) were added to $1 \mathrm{~mL}$ of sterile bi-distilled water containing $1 \mathrm{~g} / \mathrm{L}$ of RP or $4 \mathrm{~g} / \mathrm{L}$ of TCP (Sigma Aldrich, St. Quentin Fallavier Cedex, France). The mixtures were incubated at $30^{\circ} \mathrm{C}$ for five days on a rotary shaker $(180 \mathrm{rpm})$. The values obtained with the negative controls were subtracted from the values obtained with the fractions. The amount of soluble phosphate released from RP and TCP was estimated by the Olsen and Sommers method [35]. The final values are the arithmetic mean of three independent assays (Figure 3). The only fraction with both antibiotic and phosphate-solubilizing activities was fraction $\mathrm{D}$ that was selected for further investigations.

\subsection{Purification and Structure Elucidation of the Active Compound}

The active fraction D was purified by HPLC (Waters: controller 600, pump 600, dual $\lambda$ absorption detector 2487, Linear Recorder); column C18 (250 $\times 7.8 \mathrm{~mm}^{2}$ UP ODS); mobile phase: linear gradient of methanol- $\mathrm{H}_{2} \mathrm{O}$ from 0 to $100 \%$ for $52 \mathrm{~min}$; flow rate: $1 \mathrm{~mL} / \mathrm{min}$, $\lambda$ detection at $220 \mathrm{~nm}$ and at $420 \mathrm{~nm}$. The column temperature was $30^{\circ} \mathrm{C}$. The injection volume was $200 \mu \mathrm{L}$. Under these conditions, the retention time was recorded at $17.6 \mathrm{~min}$. This fraction was shown to contain two main peaks, $D_{1}$ and $D_{2}$, but only $D_{2}$ showed both phosphate-solubilizing and anti-microbial activities.

After purification of the active compound present in $\mathrm{D}_{2}$ by HPLC, the latter was subjected to spectroscopic studies. ${ }^{1} \mathrm{H}$ NMR spectroscopy: Varian Unity $500(500 \mathrm{MHz})$, Bruker 
AMX 500 (500 MHz), Varian Inova 500 (500.33 MHz). ${ }^{13} \mathrm{C}$ NMR spectroscopy: Varian Unity $500(125.8 \mathrm{MHz})$, Varian Inova $500(125.8 \mathrm{MHz})$. Chemical shifts were measured relative to tetramethylsilane as an internal standard. The homonuclear and heteronuclear 1D and 2D NMR spectra were recorded on a Varian Inova 500 instrument. Mass spectrometry was performed with an LCC ion-trap mass spectrometer (INSERM, Purpan, Toulouse). Samples were analyzed by electrospray ionization in both negative and positive ion mode, and the full-scan mass range $(\mathrm{m} / \mathrm{z})$ was 100-2000.

\subsection{Determination of the Iron Content of the Active Compound}

The presence of iron in the purified $\mathrm{D}_{2}$ compound was verified as follows. Laboratory glassware needed was kept overnight in a $5 \%$ nitric acid solution before use and then rinsed with triple-distilled water and dried in an oven. Subsequently, $3 \mathrm{mg}$ of the purified product was dissolved in $5 \mathrm{~mL}$ triple-distilled water acidified with $5 \%$ of nitric acid and heated for $30 \mathrm{~min}$ at $60^{\circ} \mathrm{C}$. The iron concentration was determined as described in Rauret et al. [36] and measured at $248.3 \mathrm{~nm}$ using a Unicam SP 969 atomic absorption spectrophotometer. A standard curve was established with a solution of $\mathrm{Fe}^{3+}\left(\mathrm{FeCl}_{3}\right.$, Sigma) in the 0.06 to $5 \mathrm{mg} / \mathrm{L}$ range.

Author Contributions: H.H. and M.C.M. performed microbial cultivations, extraction of active compounds, bio autography and anti-microbial and rock phosphate solubilizing assays. A.L., M.C.M., H.H., performed HPLC separation and purification of the bio-active compounds. A.L., M.C.M., H.H. and A.B. performed NMR spectroscopy studies and mass spectrometry analysis. M.H. determined the iron content of the active compound. Y.O. and M.J.V. conceived and supervised the project. Y.O., M.J.V. and A.L. applied for and obtained grants to fund the project and provided personnel, environmental and financial support, tools and instruments necessary for the project. M.J.V., H.H., Y.O., M.C.M. and A.L. interpreted the data and contributed to wrote the manuscript. All authors have read and agreed to the published version of the manuscript.

Funding: This research was funded by the Foreign Affairs Ministries of France and Morocco as well as by the French CNRS, the University Paris Saclay (France) and the University Cadi Ayyad (Marrakech, Morocco). Grant number CMIFM Volubilis PAI N8 MA/04/109F.

Data Availability Statement: The data supporting the findings of this study are available from the corresponding author.

Acknowledgments: We are most grateful to H. Laatsch, Institute for Organic and Biomolecular Chemistry Goettingen, for his help with viridomycin structure elucidation and validation as well as to Y. Coppel and F. Pont for their help with NMR and MS spectra.

Conflicts of Interest: The authors declare no conflict of interest.

\section{References}

1. Gyaneshwar, P.; Kumar, G.N.; Parekh, L.J.; Poole, P.S. Role of soil microorganisms in improving P nutrition of plants. Plant Soil 2002, 245, 83-93. [CrossRef]

2. Krishnaraj, P.U.; Dahale, S. Mineral phosphate solubilization: Concepts and prospects in sustainable agriculture. Proc. Indian Natl. Sci. Acad. 2014, 80, 389-405. [CrossRef]

3. Soumare, A.; Boubekri, B.; Lyamlouli, K.; Hafidi, M.; Ouhdouch, Y.; Kouisni, L. From isolation of phosphate solubilizing microbes to their formulation and use as biofertilizers: Status and needs. Front. Bioeng. Biotechnol. 2020, 7, 425. [CrossRef] [PubMed]

4. Zapata, F.; Zaharah, A.R. Phosphorus availability from phosphate rock and sewage sludge as influenced by the addition of water-soluble phosphate fertilizer. Nutr. Cycl. Agroecosyst. 2002, 63, 43-48. [CrossRef]

5. Takeda, M.; Knight, J.D. Enhanced solubilization of rock phosphate by Penicillium bilaiae in pH-buffered solution culture. Can. J. Microbiol. 2006, 52, 1121-1129. [CrossRef]

6. Rodriguez, H.; Fraga, R. Phosphate solubilizing bacteria and their role in plant growth promotion. Biotechnol. Adv. 1999, 17, 319-339. [CrossRef]

7. Vassilev, N.; Vassileva, M.; Nikolaeva, I. Simultaneous P-solubilizing and biocontrol activity of microorganisms: Potentials and future trends. Appl. Microbiol. Biotechnol. 2006, 71, 137-144. [CrossRef]

8. Wani, P.A.; Khan, M.S.; Zaidi, A. Chromium reduction, plant growth-promoting potentials and metal solubilization by Bacillus sp. isolated from alluvial soil. Curr. Microbiol. 2007, 54, 237-243. [CrossRef] 
9. Te-Hsiu, M. The international program on plant bioassays and the report of the follow-up study after the hands-on workshop in China. Mutat. Res. Fundam. Mol. Mech. Mutagenesis 1999, 426, 103-106.

10. Hamdali, H.; Bouizgarne, B.; Hafidi, M.; Lebrihi, A.; Virolle, M.J.; Ouhdouch, Y. Screening for rock phosphate solubilizing Actinomycetes from Moroccan phosphate mines. Appl. Soil Ecol. 2008, 38, 12-19. [CrossRef]

11. Hamdali, H.; Hafidi, M.; Virolle, M.J.; Ouhdouch, Y. Rock phosphate solubilizing Actinomycetes: Screening for plant growth promoting activities. World J. Microbiol. Biotechnol. 2008, 24, 2565-2575. [CrossRef]

12. Hamdali, H.; Hafidi, M.; Virolle, M.J.; Ouhdouch, Y. Growth promotion and protection against damping-off of wheat by two rock phosphate solubilizing Actinomycetes in a P-deficient soil under greenhouse conditions. Appl. Soil Ecol. 2008, 40, 510-517. [CrossRef]

13. Hamdali, H.; Smirnov, A.; Esnault, C.; Ouhdouch, Y.; Virolle, M.J. Comparative physiological studies of Actinomycetes originating from Moroccan phosphate mines and Streptomyces lividans. Appl. Soil Ecol. 2009, 44, 24-31. [CrossRef]

14. Mba, C.C. Rock phosphate solubilizing Streptosporangium isolates from casts of tropical earthworms. Soil Biol. Biochem. 1997, 29, 381-385. [CrossRef]

15. Ikeda, T. Pharmacological effects of ivermectin, an antiparasitic agent for intestinal strongyloidiasis: Its mode of action and clinical efficacy. Nippon Yakurigaku Zasshi 2003, 122, 527-538. [CrossRef]

16. Jain, P.K.; Jain, P.C. Isolation, characterization and antifungal activity of Streptomyces sampsonii GS 1322. Indian J. Exp. Biol. 2007, 45, 203-206.

17. Omura, S.; Enomoto, Y.; Shinose, M.; Takahashi, Y.; Iwai, Y.; Shiomi, K. Isolation and structure of a new antibiotic Viridomycin F produced by Streptomyces sp. K96-01 88. J. Antibiot. 1999, 52, 61-64. [CrossRef]

18. Chain, E.B.; Tonolo, A.; Carilli, A. Ferroverdin, green pigment containing iron produced by a Streptomycete. Nature 1955, 176,645 . [CrossRef]

19. Blinova, I.N.; Egorova, S.A.; Marchenko, I.V.; Saulina, L.I.; Blinov, N.O.; Khokhlov, A.S. New iron-containing antibiotics: Extraction and properties of Viridomycin A, B, and C. Khimiya Prir. Soedin. 1975, 11, 490-498.

20. Kurobane, I.; Dale, P.L.; Vining, L.C. Characterization of new viridomycins and requirements for production in cultures of Streptomyces griseus. J. Antibiot. 1987, 40, 1131-1139. [CrossRef]

21. Marchenko, I.V.; Egorova, S.A.; Blinov, N.O.; Krasilnikov, N.A. Proviridomycin-a precursor of the green pigment of Actinomycetes. Dokl. Akad. Nauk. SSSR 1968, 180, 978-980. [PubMed]

22. Yang, C.C.; Leong, J. Mode of antibiotic action of 4-hydroxy-3-nitrosobenzaldehyde from Streptomyces viridians. Antimicrob. Agents Chemother. 1981, 20, 558-562. [CrossRef] [PubMed]

23. Fiedler, H.P.; Krastel, P.; Müller, J.; Gebhardt, K.; Zeeck, A. Enterobactin: The characteristic catecholate siderophore of Enterobacteriaceae is produced by Streptomyces species. FEMS Microbiol. Lett. 2001, 196, 147-151. [CrossRef] [PubMed]

24. Liermann, L.J.; Kalinowski, B.E.; Brantley, S.L.; Ferry, J.G. Role of bacterial siderophores in dissolution of hornblende. Geochim. Cosmochim. Acta 2000, 64, 587-602. [CrossRef]

25. Sontag, B.; Gerlitz, M.; Paululat, T.; Rasser, H.F.; Grün-Wollny, I.; Hansske, F.G. Oxachelin, a Novel Iron Chelator and Antifungal Agent from Streptomyces sp. GW9/1258. J. Antibiot. 2006, 59, 659-663. [CrossRef]

26. Li, X.; Luo, L.; Yang, J.; Li, B.; Yuan, H. Mechanisms for solubilization of various insoluble phosphates and activation of immobilized phosphates in different soils by an efficient and salinity-tolerant Aspergillus niger strain An2. Appl. Biochem. Biotechnol. 2015, 175, 2755-2768. [CrossRef]

27. Vassilev, N.; Mendes, G.; Costa, M.; Vassileva, M. Biotechnological tools for enhancing microbial solubilization of insoluble inorganic phosphates. Geomicrobiol. J. 2014, 31, 751-763. [CrossRef]

28. Reyes, I.; Bernier, L.; Simard, R.R.; Tanguay, P.; Antoun, H. Characteristics of phosphate solubilization by an isolate of a tropical Penicillium rugulosum and two UV-induced mutants. FEMS Microbiol. Ecol. 1999, 28, 291-295. [CrossRef]

29. Narsian, V.; Patel, H.H. Aspergillus aculeatus as a rock phosphate solubilizer. Soil Biol. Biochem. 2000, 32, 559-565. [CrossRef]

30. Welch, S.A.; Taunton, A.E.; Banfield, J.F. Effect of microorganisms and microbial metabolites on apatite dissolution. Geomicrobiol. J. 2002, 19, 343-367. [CrossRef]

31. Mallaiah, K.V.; Sridevi, M. Production of hydroxamate-type of siderophores by Rhizobium strains from Sesbania sesban (L.). Merr. Int. J. Soil Sci. 2008, 3, 28-34. [CrossRef]

32. Frei, A.; Zuegg, J.; Elliott, A.G.; Baker, M.; Braese, S.; Brown, C.; Chen, F.; Dowson, C.G.; Dujardin, G.; Jung, N.; et al. Metal complexes as a promising source for new antibiotics. Chem. Sci. 2020, 11, 2627. [CrossRef] [PubMed]

33. Terra, L.; Dyson, P.; Ratcliffe, N.; Castro, H.C.; Vicente, A.C.P. Biotechnological Potential of Streptomyces Siderophores as New Antibiotics. Chem. Sci. 2020, 11, 2627-2639. [CrossRef] [PubMed]

34. Betina, V. Bioautography in paper and thin layer chromatography and its scope in the antibiotic field. J. Chromatogr. A 1973, 78, 41-51. [CrossRef]

35. Olsen, S.R.; Sommers, L.E. Phosphorus. In Methods of Soil Analysis, Part 2, 2nd ed.; Page, A.L., Miller, R.H., Keeny, D.R., Eds.; American Society of Agronomy: Madison, WI, USA, 1982; pp. 403-430.

36. Rauret, G.; López-Sánchez, J.F.; Sahuquillo, A.; Rubio, R.; Davidson, C.; Ure, A.; Quevauvillier, P. Improvement of the BCR three step sequential extraction procedure prior to the certification of new sediment and soil reference materials. J. Environ. Monitor. 1999, 1, 57-61. [CrossRef] 